\title{
Astronomical Alignments of Paleo-Christian Basilicas in Romania
}

\author{
Marc Frincu ${ }^{1,2, *}$, Ioana Giurginca ${ }^{2}$ \\ ${ }^{1}$ Faculty of Mathematics and Computer Science, West University of Timisoara, Romania \\ ${ }^{2}$ Romanian Society for Cultural Astronomy, Romania
}

Copyright $\bigcirc 2017$ by authors, all rights reserved. Authors agree that this article remains permanently open access under the terms of the Creative Commons Attribution License 4.0 International License

\begin{abstract}
In this paper we present the first comprehensive study of the astronomical alignments of paleo-Christian basilicas located in present day Romania. 20 basilicas from 10 sites have been investigated using a digital compass and tools such as Google Earth, Stellarium, and heywhatsthat.com. Results show that except two all fall within the solar sunrise arc. Of these some point to the rising Sun during the feast days of well-known Christian saints. The two exceptions at Argamum and Dinogeția indicate that the basilicas may be converted. The astronomical analysis in these two cases indicates a possible alignment with the moonrise during the major lunar standstill and the rising of the stars Arcturus, Castor, Mirach, and Algiebe.
\end{abstract}

$\begin{array}{ll}\text { Keywords Archaeoastronomy, } & \text { Paleo-Christian } \\ \text { Basilicas, Romania } & \end{array}$

\section{Introduction}

The foundations of Christian dogma were established in $325 \mathrm{CE}$ by the Roman emperor Constantine during the Council of Nicaea. The religion was already spreading through the Roman occupied territories and reached the Danube by the 5th century CE. The first signs of an organized Christian rite north of Danube, in today's Romania can be found in the Roman settlement from Sucidava, present day Corabia in Olt County. In nowadays Dobrogea (Scythia Minor), a region located south of Danube, between the river and the Black Sea, signs of Christianity date back to the 4th-6th centuries CE, some earlier than the ones in Sucidava. These paleo-Christian basilicas can be identified in Roman castra or settlements some erected on former Geto-Dacian and Greek settlements.

The paleo-Christian basilica was inspired from the earlier Roman civic basilica which served as a place for public gatherings, law courts, financial centers, army drill halls, reception halls and imperial palaces. Each Roman city used to have a basilica as a central public building, similarly to modern day town halls. These basilicas had an architectural form known as an apse, a semi-circular projection off the short wall of the rectangular building where the magistrate would usually sit. Later it would become the site of the altar and the ,cathedra” or the throne of the bishop [1].

Starting from as early as $200 \mathrm{CE}$ Christians have been praying facing east [2]. It is therefore not surprising that a considerable number of the paleo-Christian basilicas exhibit an east-west alignment of the apsis due to various reasons many of which have been continually disputed to this very day [3]. Examples include: 1) the Jewish custom of fixing the direction of prayer and orienting synagogues which had influenced Christianity in its early days, with many Christians praying towards the Holy Land; 2) the location of paradise; 3) the place where the third Coming or the second physical return of the Son of God will take place; 4) the orientation towards the rising point of the Sun during the basilica's patron Saint's celebration, or 5) the influence of various Sun cults. The latter is interesting not only from a history of religions perspective but also because it opens up the idea of possible solar alignments of the paleo-Christian basilicas which could have been influenced by earlier pagan rites or birth dates of various Christian saints [4-7] or of reuses of former pagan temples during the Christian Era. In fact, it is known from archaeological finds that buildings have changed their initial destination over the course of the years. Irrespective of the reason, scholars have concluded that the east-west orientation itself is important [8]. It is necessary however to note here that the same orientation can be found in civic basilicas as well [9], outlying the possibility that the orientation has not been influenced exclusively by the Christian dogma. Maxentius' basilica whose construction has been started by the same emperor in $308 \mathrm{CE}$ and completed by Emperor Constantine after his defeat in 312, is such an example. The basilica had its apse to the west, with the colossal statue of Emperor Constantine looking to the east and to the entrance of the basilica, towards the statue of the divine Sun [10]. 
Table 1. List of sites and basilicas

\begin{tabular}{|c|c|c|c|c|c|}
\hline Site Name & Lat/Long & Settlement Foundation & $\begin{array}{l}\text { Roman Conquest/ } \\
\text { Colony }\end{array}$ & Date of Basilicas & $\begin{array}{l}\text { No. of } \\
\text { Basilicas }\end{array}$ \\
\hline Adamclisi & $\begin{array}{l}44.0916^{\circ} \mathrm{N} \\
27.9438^{\circ} \mathrm{E}\end{array}$ & Geto-Dacian Settlement & $2^{\text {nd }}$ century $\mathrm{CE}$ & $4^{\text {th }}$ century $\mathrm{CE}$ & 6 \\
\hline Argamum & $\begin{array}{l}44.7582^{\circ} \mathrm{N} \\
28.9402^{\circ} \mathrm{E}\end{array}$ & $\begin{array}{c}6^{\text {th }} \text { century BCE (Greek colony) with traces of X } \\
\text { century BCE Hallstatt settlements }\end{array}$ & $1^{\text {st }}$ century $\mathrm{CE}$ & $4^{\text {th }}-7^{\text {th }}$ century CE & 3 \\
\hline Callatis & $\begin{array}{l}43.8145^{\circ} \mathrm{N} \\
28.5863^{\circ} \mathrm{E}\end{array}$ & Thracian Settlement & $1^{\text {st }}$ century $\mathrm{CE}$ & $5^{\text {th }}-6^{\text {th }}$ century CE & 1 \\
\hline Capidava & $\begin{array}{l}44.4936^{\circ} \mathrm{N} \\
28.0902^{\circ} \mathrm{E}\end{array}$ & $5^{\text {th }}-2^{\text {nd }}$ century BCE (Geto-Dacian Settlement) & $1^{\text {st }}$ century CE & $4^{\text {th }}-5^{\text {th }}$ century CE & 1 \\
\hline Dinogeția & $\begin{array}{l}45.3789^{\circ} \mathrm{N} \\
28.1387^{\circ} \mathrm{E}\end{array}$ & Getic settlement & $2^{\text {nd }}$ century $C E$ & $\begin{array}{l}4^{\text {th }} \text { century } \mathrm{CE} \\
9^{\text {th }} \text { century } \mathrm{CE}\end{array}$ & 2 \\
\hline Halmyris & $\begin{array}{l}45.0249^{\circ} \mathrm{N} \\
29.1977^{\circ} \mathrm{E}\end{array}$ & $3^{\text {rd }}$ century BCE & $2^{\text {nd }}$ century CE & $4^{\text {th }}$ century CE & 1 \\
\hline Histria & $\begin{array}{l}44.5475^{\circ} \mathrm{N} \\
28.7747^{\circ} \mathrm{E}\end{array}$ & $7^{\text {th }}$ century BCE (Greek colony) & $30 \mathrm{CE}$ & $4^{\text {th }}-6^{\text {th }}$ century CE & 2 \\
\hline Niculițel & $\begin{array}{l}45.1865^{\circ} \mathrm{N} \\
28.4843^{\circ} \mathrm{E}\end{array}$ & Roman Settlement & $1^{\text {st }}$ century CE & $4^{\text {th }}$ century CE & 1 \\
\hline Sucidava & $\begin{array}{l}43.7644^{\circ} \mathrm{N} \\
24.4591^{\circ} \mathrm{E}\end{array}$ & Dacian settlement & $3^{\text {rd }}$ century $\mathrm{CE}$ & $5^{\text {th }}$ century $\mathrm{CE}$ & 1 \\
\hline Troemsis & $\begin{array}{l}45.1333^{\circ} \mathrm{N} \\
28.1833^{\circ} \mathrm{E}\end{array}$ & Getic settlement & $1^{\text {st }}$ century CE & $5^{\text {th }}$ century CE & 2 \\
\hline
\end{tabular}

\section{Materials and Methods}

We have analyzed 20 basilicas from 11 sites. Historical and geographical details are given in Table 1. The investigated sites include basilicas from Adamclisi, Argamum, Callatis, Capidava, Dinogeia, Halmyris, Histria, Niculițel, Sucidava and Troesmis.

Where possible each basilica has been investigated by using a digital compass calibrated for the geographic north. The role of the compass was played by a Samsung Galaxy S3 with Sun Surveyor Lite app installed on it. Azimuths have been computed by measuring the angle along the exterior wall of the nave in the direction of the apsis. For cross check we have also used Google Earth to measure azimuths following the same approach. Google Earth provides an average error of $1^{\circ}$ [11]. The error of the digital compass on the smartphone is higher and equal to approximately $2.8^{\circ}[12]$.

On a number of sites (i.e., Capidava and Niculițel) access was limited due to renovation activities. In these cases, alignments have been computed using the tools provided by Google Earth.

For the site of Troemsis the location of the two basilicas could not be identified from in situ observations. Only one possible location was identified using Google Earth.

The horizon has been taken into account and computed based on the http://www.heywhatsthat.com site which relies on Google Earth for data. No clinometer was available at the time of the investigations. Horizon profiles are given in Fig. 1. Out of ten sites, five have horizons with an elevation greater than $1^{\circ}$ in the direction of the alignment: Adamclisi $\left(3.69^{\circ}\right)$, Capidava, $\left(2.61^{\circ}\right)$, Halmyris $\left(1.51^{\circ}\right)$, Niculițel $\left(2.59^{\circ}\right)$, and Troemsis $\left(1.5^{\circ}\right)$. Heywhatsthat provides higher errors for close horizons but lower for distant ones mainly due to the low spatial resolution which triggers loss of information and accuracy for close targets [11]. The mean error of the tool is of $0.5^{\circ}$. In our cases the horizon is at $5 \mathrm{~km}$ (Troemsis), $1.4 \mathrm{~km}$ (Halmyris), $1.2 \mathrm{~km}$ (Adamclisi), and $0.35 \mathrm{~km}$ (Capidava and Niculițel).

In our analysis we have considered not only major feast days prior to the schism but also possible celebrations of martyrs commemorated in Scythia Minor as listed in [13]. Four sites had complete listings: Tomis (present day city of Constanta and the capital of Scythia Minor), Noviodunum, Axiopoli (present day Cernavodă), Dinogeția, Halmyris, and Niculițel. The first three of them do not have any basilicas in our study. While each settlement had its own martyrs there is an overlap of common martyrs although celebrated at different dates (names include Cyriacus, Cyrillus, Ianuarius and Saturninus in Tomis, Cyriacus, Ianuarius and Saturninus in Noviodunum, Cyrillus and Saturninus in Axiopoli, Epicted and Astion in Halmyris and Niculițel, and Ianuarius and Saturninus in Dinogeția). The few common dates we found were those of May 25 (Tomis and Noviodunum) and October 1 (Tomis and Dinogeția). However, in both cases each site celebrated its own martyrs. This makes it impossible to validate martyrs in the region against the alignments of the basilica. Nonetheless we did consider the celebration dates from Dinogetia, Halmyris, and Niculitel in our analysis of the corresponding sites.

Furthermore, we included in the analysis martyrs not explicitly associated with a settlement. 


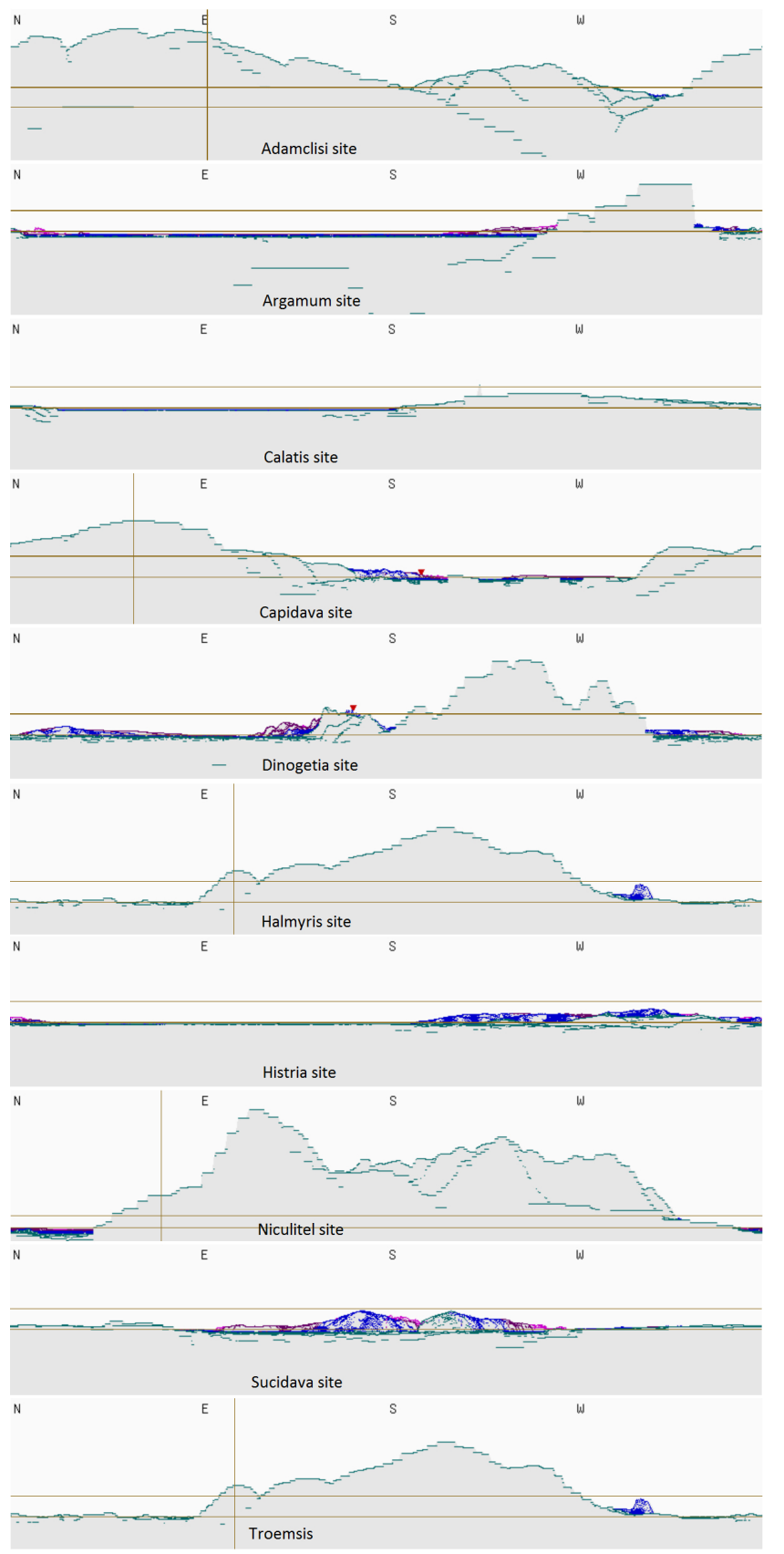

Figure 1. Horizon profiles of investigated basilicas.

A major problem when correlating feast days dating back before the introduction of the Gregorian calendar in October 1582 is the shift in the azimuth due to the realignment of the old Julian calendar with the northern vernal equinox. The new Gregorian calendar introduced a leap of 10 days in the existing Julian calendar, with October 51582 becoming October 15 1582. The Julian calendar drifts with about 1 day every 128 years. Today the drift is of approximately 13 days. In this paper we rely on present day azimuths (which for the case of the Sun changed only by aproximately $10^{\prime}$ in the past 1600 years due to precession) and use when computing the dates the Julian date as given by the Stellarium 0.15 .0 software (http://www.stellarium.org) for the period between the 4th and 6th century CE. Because of the small shift of the azimuth which does not introduce large errors, present day azimuths can be used to check the dates when the sun rises from a particular azimuth during the period of interest. In addition, these dates can be correlated with Feast days as set in the Martyrologium Hieronymianum many still in use. However, it should be noted that nowadays, the same azimuth alignment occurs 13 days later due to the calendar drift although the Feast date remained the same.

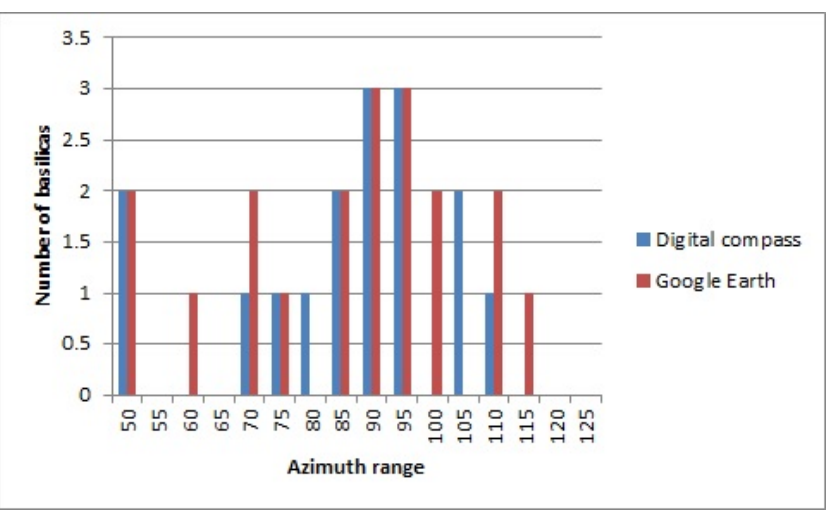

Figure 2. Histogram of the azimuth angles

\section{Results}

Azimuths at sunrise have been calculated for the centuries given in Table 1. Results are depicted in Table 2. Where $\mathrm{n} / \mathrm{a}$ is displayed the site has not been investigated using the corresponding method due to reasons explained earlier. Figure 2 presents the histogram of the azimuth orientations. In 6 out of 20 cases no difference between methods was recorded, in one case there was a $1^{\circ}$ difference, while in 6 cases the difference was greater than $5^{\circ}$. In 4 cases readings with a digital compass were not possible.

The exact or nearly exact $\left(1^{\circ}\right.$ degree difference $)$ match between the two measuring methods increases the likelihood that the azimuth values are correct and strengthens the probability that the respective basilicas are indeed oriented based on the identified Feast days.

\subsection{Orientation Analysis}

We have analyzed both Google Earth and digital compass measurements in light of their Christian significance when the orientation was inside the solar sunrise arc (i.e., azimuths between the two solstices). When outside the arc we have considered possible alignments with stars trying to infer a pagan history of the place. The eastward orientation has been motivated in the introduction. Nevertheless, it has been shown that this was not the general rule especially for medieval churches [14] where the topography of the landscape and city might have played a more important role.

Our analysis has shown that the probable alignments with 
Table 2. Orientations of basilicas (red - same value; green - values not available for both methods)

\begin{tabular}{|c|c|c|c|c|c|}
\hline \multicolumn{2}{|c|}{ Basilica } & Digital Compass & Heywhatsthat & Google Earth & Heywhatsthat \\
\hline Site & Type & Azimuth & Inclination & Azimuth & Inclination \\
\hline Adamclisi & Forensis (civic) & 93 & 3.73 & 92 & 3.73 \\
\hline Adamclisi & Transept & 87 & 3.83 & 93 & 3.73 \\
\hline Adamclisi & Simple (tank) & 83 & 3.88 & 90 & 3.73 \\
\hline Adamclisi & Bishop & 91 & 3.73 & 91 & 3.73 \\
\hline Adamclisi & Simple & 83 & 3.88 & 90 & 3.69 \\
\hline Argamum & & 66 & 0 & 66 & 0 \\
\hline Argamum & & 86 & 0 & 81 & 0 \\
\hline Argamum & & 49 & 0 & 49 & 0 \\
\hline Calatis & & 90 & 0 & 90 & 0 \\
\hline Capidava & Bishop & $\mathrm{n} / \mathrm{a}$ & $\mathrm{n} / \mathrm{a}$ & 56 & 2.61 \\
\hline Dinogeția & Byzantine & 71 & 0.11 & 71 & 0.11 \\
\hline Dinogeția & Simple & 41 & 0.25 & 41 & 0.25 \\
\hline Halmyris & Bishop & 106 & 1.42 & 110 & 1.51 \\
\hline Histria & & 101 & 0 & 106 & 0 \\
\hline Histria & Bishop & 78 & 0 & 81 & 0 \\
\hline Histria & & 94 & 0 & 98 & 0 \\
\hline Niculițel & & $\mathrm{n} / \mathrm{a}$ & $\mathrm{n} / \mathrm{a}$ & 66 & 2.59 \\
\hline Sucidava & & 105 & 0.15 & 112 & 0.24 \\
\hline Troemsis & & $\mathrm{n} / \mathrm{a}$ & $\mathrm{n} / \mathrm{a}$ & 99 & 1.5 \\
\hline Troemsis & & $\mathrm{n} / \mathrm{a}$ & $\mathrm{n} / \mathrm{a}$ & $\mathrm{n} / \mathrm{a}$ & $\mathrm{n} / \mathrm{a}$ \\
\hline
\end{tabular}

Feast days of patron saints are low with only six basilicas oriented towards significant Orthodox or pre-schism feast days in both measurement cases. Furthermore, a correlation between local martyrs and the alignments of basilicas was not found. The identified days fall within a day or exactly on the day celebrating the Annunciation, the conception and birth of St. John the Baptist, Mosses (beginning of the Orthodox New Year), and the birth and death of St. Mary the Virgin. Within two days we find the celebration of Mary's Death and the first finding of John the Baptist's head, while within three days we find John the Baptist's birth and the Meeting of the Lord. Table 3 shows the dates when the Sun rises at the given azimuth and altitude and the possible correlation with patron saints.

Overall $62.50 \%$ (for the digital compass analysis), respectively $57.90 \%$ (for Google Earth analysis) of basilicas have azimuths less or equal to $90^{\circ}$. The highest concentration of basilicas pointing towards SE were at the sites of Halmyris (both methods), Histria (both methods for two of the three basilicas), Sucidava, and Troemsis (Google Earth method only). For the Adamclisi site Google Earth gives east and $\mathrm{SE}$ orientations for all basilicas whereas the digital compass only gave two such cases. All orientations pointing to feast days are oriented towards NE.

\subsection{The Cases of Argamum and Dinogeția}

Two basilicas at Argamum (basilica 1) and Dinogeția fall outside of the solar arc. We emphasize here that both methods provided the same azimuth values in their cases. We hypothesize in their cases two scenarios. First, we theorize that they had been laid out without relying on accurate orientations roughly towards north-east and facing Summer solstice sunrise due to geographical and planning constraints; secondly, we theorize that they point out towards other important rising points during the year such as those of the Moon or the stars. The summer solstice alignment hypothesis is problematic since the horizon is flat with no reason to deviate due to geographical considerations and simple visual observations could have been probably sufficient to approximate the orientation which much higher precision. Current orientations are off by five degrees (Argamum), respectively $13^{\circ}$ (Dinogetia). However the solar alignment hypothesis cannot be completely dismissed as these deviations may indicate a role of the settlement layout and of the constant changes in destination buildings in the era suffered from. 
Table 3. Sunrise dates correlated for the azimuth and inclination.

\begin{tabular}{|c|c|c|c|c|c|c|c|c|}
\hline Basilica & \multicolumn{4}{|c|}{ Orientation using compass } & \multicolumn{4}{|c|}{ Orientation using Google Earth } \\
\hline Site & Date & Celebration & Date & Celebration & Date & Celebration & Date & Celebration \\
\hline Adamclisi & $21 / 3 / 350$ & & $23 / 9 / 350$ & $\begin{array}{c}\text { John Baptist } \\
\text { (conception) - } \\
\text { celebrated on Sep } \\
23 \\
\end{array}$ & $22 / 3 / 350$ & & $21 / 9 / 350$ & \\
\hline Adamclisi & $1 / 4 / 350$ & & $13 / 9 / 350$ & & $20 / 3 / 350$ & & $22 / 9 / 350$ & $\begin{array}{c}\text { John Baptist } \\
\text { (conception) - } \\
\text { celebrated on } \\
\text { Sep } 23 \\
\end{array}$ \\
\hline Adamclisi & $8 / 4 / 350$ & & $5 / 9 / 350$ & & $21 / 3 / 350$ & & $18 / 9 / 350$ & \\
\hline Adamclisi & $24 / 3 / 350$ & Annunciation & $19 / 9 / 350$ & & $24 / 3 / 350$ & Annunciation & $19 / 9 / 350$ & \\
\hline Adamclisi & $8 / 4 / 350$ & & $5 / 9 / 350$ & & $21 / 3 / 350$ & & $18 / 9 / 350$ & \\
\hline Argamum & $4 / 5 / 450$ & $\begin{array}{c}\text { Andrew and } \\
\text { Philip apostles } \\
\text { - celebrated on } \\
\text { May } 1\end{array}$ & $9 / 8 / 450$ & & $4 / 5 / 450$ & $\begin{array}{c}\text { Andrew and } \\
\text { Philip apostles } \\
\text { - celebrated on } \\
\text { May } 1\end{array}$ & $9 / 8 / 450$ & \\
\hline Argamum & $25 / 3 / 450$ & Annunciation & $16 / 9 / 450$ & & $3 / 4 / 450$ & & $8 / 9 / 450$ & $\begin{array}{l}\text { St. Mary the } \\
\text { Virgin (birth) - } \\
\text { celebrated on } \\
\text { Sep } 8\end{array}$ \\
\hline \multicolumn{9}{|l|}{ Argamum } \\
\hline Calatis & $18 / 3 / 450$ & & $23 / 9 / 450$ & $\begin{array}{c}\text { John Baptist } \\
\text { (conception) - } \\
\text { celebrated on Sep } \\
23 \\
\end{array}$ & $18 / 3 / 450$ & & $23 / 9 / 450$ & $\begin{array}{l}\text { John Baptist } \\
\text { (conception) }\end{array}$ \\
\hline Capidava & & & & & $21 / 6 / 450$ & $\begin{array}{l}\text { John Baptist } \\
\text { (birth) - } \\
\text { celebrated on } \\
\text { Jun } 24\end{array}$ & & \\
\hline Dinogeția & $19 / 4 / 850$ & & $17 / 8 / 850$ & $\begin{array}{l}\text { St. Mary the } \\
\text { Virgin (death) - } \\
\text { celebrated on } \\
\text { Aug } 15\end{array}$ & $19 / 4 / 850$ & & $17 / 8 / 850$ & $\begin{array}{c}\text { St. Mary the } \\
\text { Virgin (death)- } \\
\text { celebrated on } \\
\text { Aug } 15\end{array}$ \\
\hline \multicolumn{9}{|l|}{ Dinogeția } \\
\hline Halmyris & $21 / 2 / 350$ & & $19 / 10 / 350$ & & $14 / 2 / 350$ & & $26 / 10 / 350$ & \\
\hline Histria & $27 / 2 / 350$ & & $13 / 10 / 350$ & & & & $23 / 10 / 350$ & \\
\hline Histria & $8 / 4 / 550$ & & $1 / 9 / 550$ & $\begin{array}{l}\text { Moses (Orthodox } \\
\text { New Year) }\end{array}$ & $3 / 4 / 550$ & & $7 / 9 / 550$ & $\begin{array}{l}\text { St. Mary the } \\
\text { Virgin (birth) - } \\
\text { celebrated on } \\
\text { Sep } 8\end{array}$ \\
\hline Histria & $11 / 3 / 350$ & & $1 / 10 / 350$ & & $5 / 3 / 350$ & & $8 / 10 / 350$ & \\
\hline Niculițel & & & & & $2 / 8 / 350$ & & $12 / 5 / 350$ & \\
\hline Sucidava & $26 / 2 / 450$ & $\begin{array}{l}1^{\text {st }} \text { finding of } \\
\text { the precious } \\
\text { head of St. } \\
\text { John the } \\
\text { Baptist ( } 4^{\text {th }} \\
\text { century) - } \\
\text { celebrated on } \\
\text { Feb } 24\end{array}$ & $13 / 10 / 450$ & & $5 / 2 / 450$ & $\begin{array}{l}\text { Meeting of the } \\
\text { Lord - } \\
\text { celebrated on } \\
\text { Feb } 2\end{array}$ & $3 / 11 / 450$ & \\
\hline Troemsis & & & & & $5 / 3 / 450$ & & $6 / 10 / 450$ & \\
\hline Troemsis & & & & & & & & \\
\hline
\end{tabular}


In the case of Argamum all three basilicas including the one facing to an azimuth of $49^{\circ}$ are built near the edge of the cliff (cf. Fig. 3) and there is no reason why they could not have been oriented differently, unless the builders wanted the basilica to be perpendicular to the cliff or the basilica was a converted building. The problem in the first case is twofold: we do not know the layout of the layout of the shore 2,000 years ago, and the other two basilicas at the Argamum site do not follow this template. Analyzing the second case we discover from archaeological investigations that the basilica predates the city wall which was modified to go around the apsis [15]. The wall was built by byzantine emperor Justinian (527-565 CE) and investigations performed by archaeologists in 2001 proved the existence of Greek housing remains dating from the archaic period (6th century $\mathrm{BCE}$ ) in the area of basilica 3 which is also located inside the city walls. Detailed excavations around basilica 3 are however not possible due to the existence of numerous roman and byzantine artefacts in upper layers. Investigations at basilica 1 , our subject, indicate that the solid rock is only $0.1-0.35 \mathrm{~m}$ beneath the ground level.
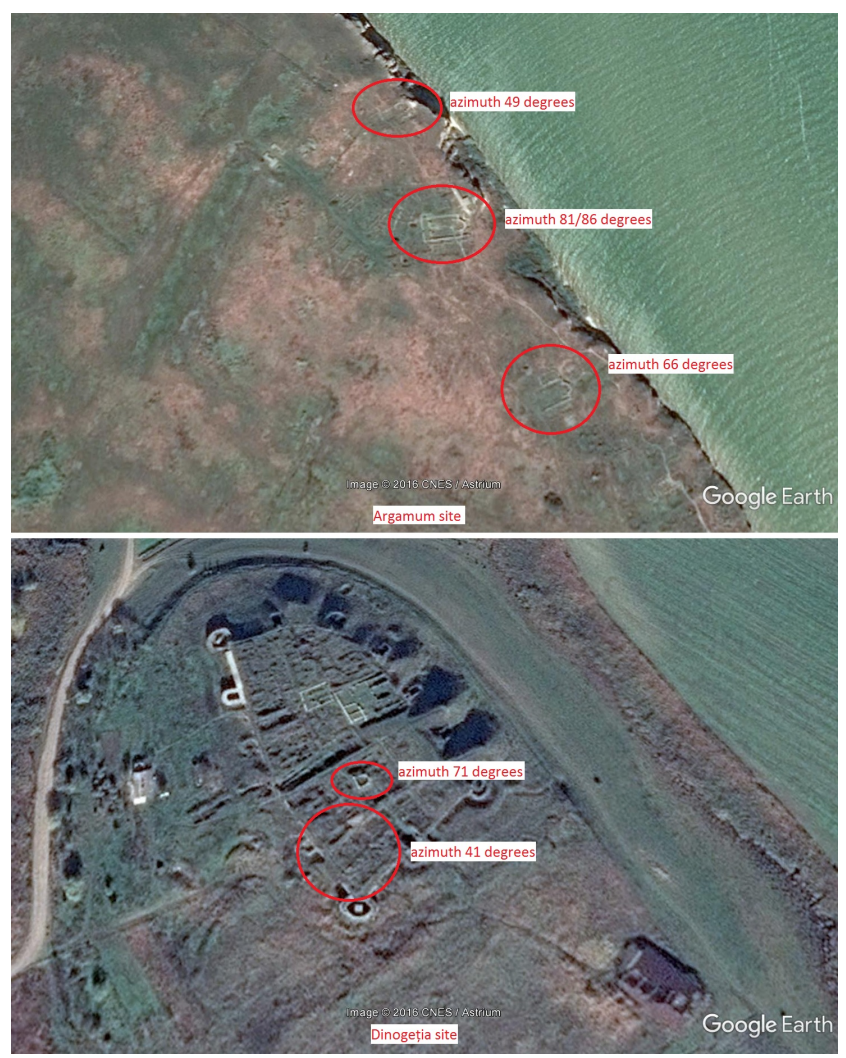

Figure 3. Satellite view of Argamum and Dinogeția sites

In 2001, excavations have demonstrated the existence of a thin layer of clay and a wall which predates the basilica and seems to have been used to consolidate the rock cliff. In 2002 , investigations dated the basilica in the second half of the 5th century CE [16]. Dating is based on the previously identified wall remains which predate the construction of the basilica. If this dating is correct then the basilica is indeed of paleo-Christian origins, being the oldest in
Argamum. Therefore, it is not unlikely for it to be based on an existing building which was converted to its new role of basilica around the time the wall was built or immediately before it. As proof we have both the simple design of the basilica with a single nave whereas basilicas 2 and 3 have three naves, and the NE orientation outside the solar sunrise arc. Concluding, while we agree with the archaeologists on the basilica date we do not exclude the possibility of the building to be of older origins given its strange orientation which could have been easily aligned with the sunrise, as it is the case of the other two basilicas, had the building been built intentionally as a basilica. The building was chosen probably due to its NE orientation and location on the edge of the cliff offering a splendid view of the sea.

At Dinogetia we find the opposite case. Here, the city planning probably played a role in the orientation of the basilica, which at azimuth of $41^{\circ}$ is parallel with the outer wall (cf. Fig. 4). Archaeological records about the basilica are lacking with most of the work being focused on restauration and investigations in other areas of the site [17]. While there are some theories about a former Getic settlement in the area the current castrum seems to be entirely of roman and byzantine origins. Hence, as in the case of basilica 1 at Argamum which was chosen due to the geographical orientation of the existing building, at Dinogeția the basilica was probably built facing NE, approximating the solar summer solstice sunrise, due to constraints caused by the city wall layout.

While we have offered plausible architectural reasons for the NE orientation outside the solar sunrise arc, we analyze next the Lunar and stellar alignment hypothesis. In addition, the analysis provides a purpose for the building on which basilica 1 at Argamum was built and a possible indication of an older temple at Dinogeția. These raise the interesting possibility of pagan influences through either infusion of traditions or converted pagan temples.

Considering the orbit of the Moon around Earth we notice that its rising point varies similarly to that of the Sun, although at a slower pace in a 18.6 years cycle where the extreme fluctuations in azimuth are known as major and minor standstills. During a major lunar standstill and within the period of a month the Moon will have the widest variation in azimuth. 9.3 years later it will reach the minor lunar standstill when within a month's timeframe its azimuth variation will be the smallest. For the geographical position of $45^{\circ}$ north and $28^{\circ}$ longitude east, the minimum azimuth at major lunar standstill is of $47.365^{\circ}$ in $500 \mathrm{CE}$ and $47.158^{\circ}$ in 500 BCE. At minor lunar standstill the minimum azimuth is of $63.999^{\circ}$ in $500 \mathrm{CE}$ and $63.815^{\circ}$ in 500 BCE. This small deviation of less than half a degree across a millennium means that it is not unlikely that an older temple dating back from the early Greek colonists or Getic period could have been responsible for the alignment.

By comparing these values with that of the two basilicas we notice that one basilica at Argamum is oriented at $49^{\circ}$ azimuth. While this is close it is still more than one degree 
off. By analyzing using Stellarium the rising points of stars we notice three candidates within one degree of azimuth: Arcturus (48 $\left.31^{\prime \prime}\right)$, Mirach (49 44"), and Algieba (50 $\left.02^{\circ} "\right)$. As evidenced by findings near basilica 3 artifacts from the Greek stage of the settlement are present in the area and we know Greeks were aware of the Metonic lunar cycle ${ }^{1}$ implying they studied both the eclipses and the rise and set points of the Moon. Pagan Greek temples are known to have been astronomically aligned since at least the 7 th century BCE [18]. In Greece, a 7th century BCE temple dedicated to the goddess Aphrodite was oriented towards an azimuth of $44^{\circ}$. Probabilistic analysis has showed that it is unlikely that the East orientation of the Greek temples is by chance and has to do with various astronomical alignments, be it the Sun, the Moon, or stars. In addition, a comprehensive analysis of 107 temples has emphasized the solar alignment of $58 \%$ of the temples with one example being a possible lunar alignment and others oriented towards the heliacal rising ${ }^{2}$ of various stars [19].

The basilica at Dinogeția faces the $41^{\circ}$ azimuth point making it an unlikely candidate for a lunar orientation. Furthermore, by analyzing the rising points of the stars we notice that the Alpha Gemini (Castor) rises from an azimuth of approx. $40^{\circ}$. Beta Gemini (Pollux) rises from approx. $45^{\circ}$ azimuth. We know from studies of Roman temples that some are aligned with star rising points [20]. However, in the case of Dinogeția (founded 2nd century CE) we do not have any current archaeological evidence of a prior destination of the basilica dating in the 4 th century CE. Finally, we emphasize here the high probability of chance due to the exterior castrum wall which was probably built before the buildings and which probably caused the architectural layout of the buildings inside the castrum.

\section{Conclusions}

In this paper we have analyzed 20 basilicas from 10 sites using a digital compass and tools such as Google Earth, Stellarium, and heywthatsthat.com. We have found that the measurements taken using the digital compass differ in some cases from the Google Earth data and we have considered both data in our analysis. Results show that except two cases at Argamum and Dinogeția all basilicas fall within the solar sunrise arc with few pointing to the feast days of important Christian saints. For these two cases both Google Earth and digital compass analysis agree on their orientation. A particular importance has been given to investigating the causes for the Argamum and Dinogeția strange alignments. In their case we started our analysis from the archaeological findings and have emphasized the probability of the basilicas

1 A period of time of approx. 19 years that is a common multiple of the solar year and the synodic (lunar) month.

2 The heliacal rising of a star is the moment when that star first becomes visible in the morning after a period of invisibility due to it being behind the Sun. As a result the phenomenon takes place in the early hours of the morning right before the sunrise. to be placed on former buildings with different destinations (a possible pagan temple at Dinogeția and an unknown building at Argamum). In particular, our analysis shows a possible alignment with the major lunar standstill or with that of several stars (Arcturus, Mirach, and Algiebe) at Argamum, and with Castor at Dinogeția.

This study is the first one performed on paleo-Christian basilicas in sites located in present day Romania. Our analysis and findings complement and in some cases, such as for the Argamum site, strengthen existing archaeological data. Results also provide insight on the patron saints of some basilicas. Finally, while not a target of the study, no connection between the alignments of the basilicas and St. Andrew, the saint which supposedly Christianized the land in present day Romania was found. Such evidence would have provided the first physical proof of St. Andrew's warship and presence in Scythia Minor, present day region of Dobrogea in Romania.

Our analysis also provided an insight on how different modern day tools and devices available for everyone can provide different results, outlying the importance of cross validation based on different sources and the importance of knowing the error of the measurements.

\section{REFERENCES}

[1] Marilyn Stockstad, Medieval Art 2nd Edition, Westview Press, USA, 2004.

[2] Cyrille Vogel et al., Sol æquinoctialis. Problèmes et technique de l'orientation dans le culte chrétien, Revue des Sciences Religieuses, Vol. 36, No. 3, pp. 175-211, 1962.

[3] Charles Herbermann, Orientations of Churches - Catholic Encyclopedia, Robert Appleton Company, USA, 1913.

[4] George Pantazis, Evangelia Lambrou, On the Date of Early Christian Basilicas (early Greece), Mediterranean Archaeology and Archaeometry, Vol. VI, No. 3, pp. 53-60, 2006.

[5] Hugh Benson, Church Orientations and Patronal Festivals, The Antiquaries Journal, Vol. 36, No. 3-4, pp. 205-213, 1956.

[6] Sasa Caval, Astronomical Orientations of Sacred Architecture during the Medieval Period in Slovenia, Cosmology Across Cultures, ASP Conference series, Vol. 409, pp. 209-219, 2009.

[7] Heinrich Nissen, Orientation. Studien zur Geschichte de Religion, Berlin: Weidmannsche Buchhndlung, 1906.

[8] Olof Brandt, The Archaeology of Roman Ecclesial Architecture and the Study of Early Christian Liturgy, Studia Patristica, Vol. LXXI, pp. 21-52, 2010.

[9] Carlo Giavarini, The Basilica of Maxentius. The Monument, its Materials, Construction and Stability, Roma: L'Erma di Bretschneider, Italy, 2005. 
[10] Brandt, The Archaeology of Roman Ecclesial Architecture and the Study of Early Christian Liturgy, p. 21-52.

[11] Andrea Rodríguez-Antón, A. César González-García and Juan Antonio Belmonte, Estimating the Reliability of the Digital Data Acquisition in Cultural Astronomy. The case of the Roman North Africa, abstract of SEAC Conference, 2016.

[12] Viktor Reisj, Skyline Tools and Theodolite Apps for Archeoastronomy, Online available from http://www.slideshare.net/vreijs1/skyline-azimuth-and-altitu de-tools-for-archaeoastronomy [accessed on 17th December 2016].

[13] Nicolae Danilă, Martyrologium Daco-Romanum, Danubius, Galati, 2002.

[14] Ian Hinton, Church Alignment and Patronal Saint's Days, British Archaeology, Vol. 94, pp. 28-29, 2006.

[15] Florin Topoleanu et al., Year 2000 Report on Argumum site archaeological investigations, Online available from http://cronica.cimec.ro/detaliu.asp?k=1008\&d=Jurilovca-Tul cea-Capul-Dolojman-2000 [accessed on $30^{\text {th }}$ December 2016].

[16] Florin Topoleanu, Iulian Vizauer, Vera Rusu, Monica Margineanu-Carstoiu, Stefan Balici, Virgil Apostol, Year
2002 report on Argamum site archaeological investigations, Online available from

http://cronica.cimec.ro/detaliu.asp?k=2002\&d=Jurilovca-Tul cea-Capul-Dolojman-2002 [accessed on $30^{\text {th }}$ December 2016]

[17] Annon., Castrum of Dinogeția, Online available from http://ran.cimec.ro/?codran=160635.03 [accessed $30^{\text {th }}$ December 2016].

[18] Alun Salt, The Astronomical Alignments of Ancient Greek Temples, PLoS ONE, Vol. 4, No. 11, 2009, Online available from

http://journals.plos.org/plosone/article?id=10.1371/journal.p one.0007903 [accessed on 21st December 2016].

[19] Efrosyni Boutsikas, Placing Greek Temples: An Archaeoastronomical Study of the Orientation of the Ancient Greek Religious Structures, The Journal of Astronomy in Culture, Vol. XXI, pp. 4-19, 2009.

[20] Vance Tiede, Graeco-Roman Astro-Architecture: The Temples of Pompeii (PPT slides revised 1 June 2014), Available online from https://www.academia.edu/5008886/Graeco-Roman_AstroArchitecture_The Temples_of_Pompeii_PPT_slides_revise d_1_June_2014_[accessed on $30^{\text {th }}$ December 2016$]$. 